\title{
Analisis Kandungan Vitamin Pada Melon (Cucumis melo L.) Kultivar Melodi Gama 1 dan Melon Komersial
}

\author{
BUDI SETIADI DARYONO ${ }^{1}$, SIGIT DWI MARYANTO ${ }^{2}$, SHOLIHATUN NISSA ${ }^{2}$, GANIES \\ RIZA ARISTYA ${ }^{1}$ \\ ${ }^{1}$ Laboratorium Genetika, Fakultas Biologi, Universitas Gadjah Mada \\ Jl. Teknika Selatan, Sekip Utara, Yogyakarta 55281 \\ email: bs_daryono@yahoo.com \\ ${ }^{2}$ Mahasiswa Fakultas Biologi, Universitas Gadjah Mada \\ Jl. Teknika Selatan, Sekip Utara, Yogyakarta 55281
}

\begin{abstract}
As many as 50 million people worldwide are currently experiencing a deficiency of vitamin A and about 250000-500000 malnourished children in developing countries become blind each year from vitamin A deficiency, with the highest prevalence in Southeast Asia and Africa which will result in visual impairment, and increased child mortality and pregnant women. Melon can be one of the solutions for higher productivity and fruit may contain carotene (pro-vitamin A) with varying levels. In the years 2009-2011 Genetics laboratory, faculty of Biology UGM has produced a new melon cultivar called Melodi Gama 1 (MG 1). MG 1 phenotype has a rounded character with rather thick rind and hard, green and fleshy with a smooth orange flesh color. The purpose of this research was to study and analyze the nutritional content of MG 1 compared to commercial cultivars from multilocation and multiseason cultivation. The methods were used vitamin A quantitative analysis by extraction and spectrophotometer, whereas vitamin $\mathrm{C}$ in quantitative analysis using the iodine titration method. The results obtained in the analysis of total carotene in the dry season for the MG 1 has the highest value compared with 4 other commercial cultivars, it was $706.61 \mu \mathrm{g} / 100 \mathrm{gr}$ for cultivation in Yogyakarta and $292.16 \mu \mathrm{g} / 100 \mathrm{gr}$ for cultivation in Magetan. In the rainy season total carotene MG 1 was $59.88 \mu \mathrm{g} / 100 \mathrm{gr}$ for cultivation in Yogyakarta, and $20.76 \mu \mathrm{g} / 100 \mathrm{gr}$ for cultivation in Magetan. The results of the quantitative analysis of vitamin C MG 1 in the dry season was $7.50 \mathrm{mg} / 100 \mathrm{gr}$ for cultivation in Yogyakarta and $16.50 \mathrm{mg} / 100 \mathrm{gr}$ for cultivation in Magetan, while the rainy season was $8.55 \mathrm{mg} / 100 \mathrm{gr}$ for cultivation in Yogyakarta and $6.75 \mathrm{mg} / 100 \mathrm{gr}$ for cultivation in Magetan. Based on these results it can be concluded that the content of Vitamin A and $\mathrm{C}$ from Melodi Gama 1 cultivar is higher in the dry season than in the rainy season.
\end{abstract}

Keywords: Cucumis melo L., multilocation, multiseason, total carotene, vitamin C

\section{INTISARI}

Menurut laporan WHO, sebanyak 50 juta penduduk dunia saat ini mengalami defisiensi vitamin A dan sekitar 250.000-500.000 anak kurang gizi di negara berkembang menjadi buta setiap tahun akibat kekurangan vitamin A dengan prevalensi tertinggi di Asia Tenggara dan Afrika yang akan berakibat pada gangguan penglihatan, serta meningkatkan angka kematian anak dan wanita hamil. Melon dapat menjadi salah satu solusi karena produktivitasnya yang tinggi dan buahnya dapat mengandung karoten (pro vitamin A) dengan kadar bervariasi. Pada tahun 2009-2011 telah dilakukan perakitan melon unggul kultivar Melodi Gama 1 yang memiliki karakter fenotip berbentuk bulat dengan kulit buah agak tebal dan keras, berwarna hijau serta berdaging halus dengan warna daging buahnya berwarna orange. Tujuan penelitian ini adalah mempelajari serta menganalisis kandungan nutrisi buah melon kultivar Melodi Gama 1 dibandingkan kultivar komersial pada multilokasi dan multimusim. Metode yang digunakan untuk analisis vitamin A secara kuantitatif dengan ekstraksi dan spektrofotometri, sedangkan analisis vitamin C secara kuantitatif menggunakan metode titrasi dengan Iodium. Hasil yang diperoleh pada analisis total karoten pada musim kemarau untuk kultivar Melodi Gama 1 memiliki nilai tertinggi dibandingkan 
dengan 4 kultivar komersial lainnya yaitu 706,61 $\mu \mathrm{g} / 100 \mathrm{gr}$ untuk lokasi tanam di Yogyakarta dan 292,16 $\mu \mathrm{g} / 100 \mathrm{gr}$ untuk lokasi tanam di Magetan. Pada musim hujan total karoten Melodi Gama 1 yaitu 59,88 $\mu \mathrm{g} / 100 \mathrm{gr}$ untuk lokasi tanam di Yogyakarta dan 20,76 $\mu \mathrm{g} / 100 \mathrm{gr}$ untuk lokasi tanam di Magetan. Hasil analisis kuantitatif vitamin C kultivar Melodi Gama 1 pada musim kemarau yaitu 7,50 mg/100gr untuk lokasi tanam di Yogyakarta dan 16,50 mg/100gr untuk lokasi tanam di Magetan, sedangkan pada musim hujan yaitu 8,55 mg/100gr untuk lokasi tanam di Yogyakarta dan $6,75 \mathrm{mg} / 100 \mathrm{gr}$ untuk lokasi tanam di Magetan. Berdasarkan hasil penelitian dapat disimpulkan bahwa kandungan Vitamin A dan C buah melon Melodi Gama 1 lebih tinggi pada musim kemarau dibandingkan pada musim hujan.

Kata kunci: Cucumis melo L., multilokasi, multimusim, total karoten, vitamin C

\section{PENDAHULUAN}

Sekitar 50 juta penduduk dunia saat ini mengalami defisiensi vitamin A. Di negara berkembang ditemukan bahwa sekitar 250.000-500.000 anak mengalami kekurangan gizi dan mengalami kebutaan setiap tahunnya. Hal ini disebabkan oleh kekurangan vitamin A dengan prevalensi tertinggi di Asia Tenggara dan Afrika yang akan berakibat pada gangguan penglihatan, serta meningkatkan angka kematian anak dan wanita hamil (WHO, 2010). Tanaman melon (Cucumis melo L.) merupakan tanaman budidaya yang akhir-akhir ini banyak dikonsumsi oleh masyarakat Indonesia. Melon juga menjadi komoditas ekspor Indonesia ke berbagai negara antara lain Singapura, Malaysia, Jepang, Korea, dan Hongkong. Oleh karena itu melon dapat menjadi salah satu solusi mengatasi kekurangan gizi terutama vitamin karena produktivitasnya yang tinggi dan buahnya dapat mengandung karoten (pro vitamin $\mathrm{A}$ ) dan mengandung vitamin $\mathrm{C}$ yang cukup tinggi (Daryono dkk, 2011).

Melon merupakan salah satu tanaman buah dari famili Cucurbitaceae yang potensial untuk dikembangkan dalam pemuliaan tanaman (Maryanto and Daryono, 2011). Tanaman melon termasuk dalam divisio Spermatophyta karena termasuk dalam tumbuhan berbiji, sub-divisio Angiospermae.

Kultivar Melodi Gama 1 merupakan hasil pengembangan melalui pemuliaan tanaman. Kultivar Melodi Gama 1 merupakan hasil seleksi dari TC4 yaitu melon hasil uji silang (test cross) antara induk jantan F1B dengan induk betina Andes (Alaydrus, 2004). Test cross dilakukan dengan mengawin-balikkan keturunan F1 dengan salah satu induknya yang dobel resesif.

Kultivar Melodi Gama 1 memiliki karakter fenotip antara lain bentuk buah bulat, kulit buah agak tebal dan keras, kulit buah berwarna hijau, nett jelas dan rapat, warna daging buah jingga (orange), tekstur daging buah lembut, aroma harum, dan rasa manis (Maryanto and Daryono, 2011).

Daging buah melon mengandung 92,1\% air; $1,5 \%$ protein; $0,3 \%$ lemak; $6,2 \%$ karbohidrat; $0,5 \%$ serat; $0,4 \%$ abu dan Vitamin A 357 IU (3). Buah melon ini menjadi salah satu buah sumber energi karena dalam 100 gram berat yang dapat dimakan mengandung kalori (21 kal), karbohidrat $(5,1$ gram), protein (0,6 gram), lemak (0,1 gram) dan beberapa vitamin serta mineral lain yang sangat dibutuhkan untuk tumbuh (Prajnanta, 2004).

Vitamin merupakan senyawa organik tertentu yang diperlukan dalam jumlah kecil, namun memiliki peran penting bagi kelangsungan pertumbuhan energi, fungsi saraf dan memelihara kesehatan tubuh. Vitamin dibedakan menjadi 2 golongan yaitu vitamin yang mampu larut dalam lemak dan larut dalam air (Almatsier, 2004). Vitamin A, $\mathrm{D}, \mathrm{E}, \mathrm{K}$ merupakan vitamin yang mampu larut dalam lemak sehingga memerlukan lemak agar dapat diserap oleh tubuh, sedangkan vitamin B kompleks dan $\mathrm{C}$ larut dalam air (Winarno, 2008).

Kultivar Melodi Gama 1 merupakan kultivar baru hasil perakitan yang belum diketahui kandungan vitamin. Untuk menjadi kultivar unggulan, Melodi Gama 1 perlu 
dilakukan penanaman secara multilokasi dan multimusim bersama kultivar komersial lainnya agar diketahui kestabilan dan keseragaman karakter fenotip buah melon (Daryono dan Aristya, 2009).

Kandungan nutrisi buah merupakan salah satu karakter fenotip buah yang masih perlu dilakukan penelitian. Tujuan penelitian ini adalah mempelajari serta menganalisis kandungan vitamin buah melon kultivar Melodi Gama 1 dibandingkan kultivar komersial pada multilokasi dan multimusim.

\section{METODE}

Penelitian dilakukan pada musim kemarau dan musim hujan. Penanaman melon yang akan diuji dilakukan di 2 lokasi yaitu Kebun Pendidikan Penelitian dan Pengembangan Pertanian (KP4) UGM Yogyakarta, dan Magetan. Pengujian sampel dilakukan di Laboratorium Genetika Fakultas Biologi UGM dan Fakultas Teknologi Pertanian UGM.

Penentuan karotenoid total. Seberat 5 mg daging buah melon dimasukkan ke dalam labu (13 x $100 \mathrm{ml})$, setelah itu diekstraksi sebanyak $3 \mathrm{x}$ dengan $5 \mathrm{ml}$ petrolium eteraseton $(1: 1 \mathrm{v} / \mathrm{v})$. Dari ekstraksi tersebut diperoleh sepernatan dan residu. Supernatan yang diperoleh dapat dibedakan menjadi 2 yakni fase air-aseton dan fase petroleum eterkarotenoid. Kemudian ditambahkan $\mathrm{Na}_{2} \mathrm{SO}_{4}$ anhidrous. Setelah itu diencerkan dengan petrolium eter hingga $10,0 \mathrm{ml}$ labu ukur altakar. Dilakukan penggojogan lalu dimasukkan dalam kuvet $1 \mathrm{~cm}$ lalu dibaca absorbansinya pada $\lambda=450 \mathrm{~nm}$ (dengan blanko petrolium eter).

Vitamin C (dengan titrasi yodium). Penentuan kadar vitamin $\mathrm{C}$ menggunakan metode titrasi yodium yaitu daging buah melon seberat 200-300 gram dihancurkan dalam Waring blender sampai diperoleh slurry. Slurry 10-30 gram dimasukkan ke dalam labu takar $100 \mathrm{ml}$ dan tambahkan aquades sampai tanda.
Saringan dengan krus Gooch atau dengan sentrifug untuk memisahkan filtratnya. Diambil $10 \mathrm{ml}$ filtrat dengan pipet gondok dan dimasukkan ke dalam erlenmeyer $125 \mathrm{ml}$. Ditambah $2 \mathrm{ml}$ larutan amilum 1\% (soluble starch) dan ditambahkan $20 \mathrm{ml}$ aquades. Kemudian dititrasi dengan $0,01 \mathrm{~N}$ standard yodium.

Analisis data. Pengambilan sampel untuk uji kandungan vitamin $\mathrm{A}$ dan $\mathrm{C}$ dilakukan secara acak sebanyak 3 ulangan untuk masing-masing kultivar. Untuk penghitungan karoten total yaitu:

$$
\begin{aligned}
& \% \text { karotenoida }=\frac{\text { berat karotenoida }}{\text { berat sampel }} \times 100 \% \\
& \text { Berat sampel } \quad=100 \mathrm{mg}=0,1 \mathrm{~g} \\
& \text { Berat karotenoida }=\frac{\mathrm{EY}}{1 \%}
\end{aligned}
$$

$$
\begin{aligned}
\mathrm{E}^{1 \%}{ }_{1 \mathrm{~cm}=} & \text { koefisien ekstingsi spesifik pada } \lambda \\
& \text { yang dipakai dengan pelaut yang } \\
& \text { digunakan \& tebal kuvet } 1 \mathrm{~cm} . \\
\mathrm{E}^{1 \%}{ }_{1 \mathrm{~cm}=} & \text { karotenoida dalam petroleum eter } \\
& \text { pada kuvet setebal } 1 \mathrm{~cm} \text { adalah } \\
& 2500 .
\end{aligned}
$$

Maka EY = koefisien eksistensi

$$
\begin{aligned}
& \% \text { berat karotenoid }= \\
& \frac{\text { absorbansi } \times \text { faktor pengenceran }}{E 1 \% 1 \mathrm{~cm} \times \text { tebal sampel }} \times 100 \%
\end{aligned}
$$

Berat karotenoid $=\frac{\text { absorbansi } \times 10}{2500 \times 100 \mathrm{mg}} \times 100 \%$

$\%$ Karotenoida $=\frac{\text { absorbansi } \times 10}{0,050 \mathrm{mg}} \times 100 \%$

$\mathrm{mg} \%$ karotenoida $=20$ absorbansi $(\mathrm{mg} / 100 \mathrm{~g})$

Untuk penghitungan kadar vitamin $\mathrm{C}$ buah melon menggunakan rumus: $1 \mathrm{ml} 0,01$ $\mathrm{N}$ Yodium $=0,88 \mathrm{mg}$ asam askorbat. Hasil perhitungan kadar vitamin $\mathrm{A}$ dan $\mathrm{C}$ tiap kultivar kemudian dibandingkan secara statistik menggunakan diagram. 


\section{HASIL}

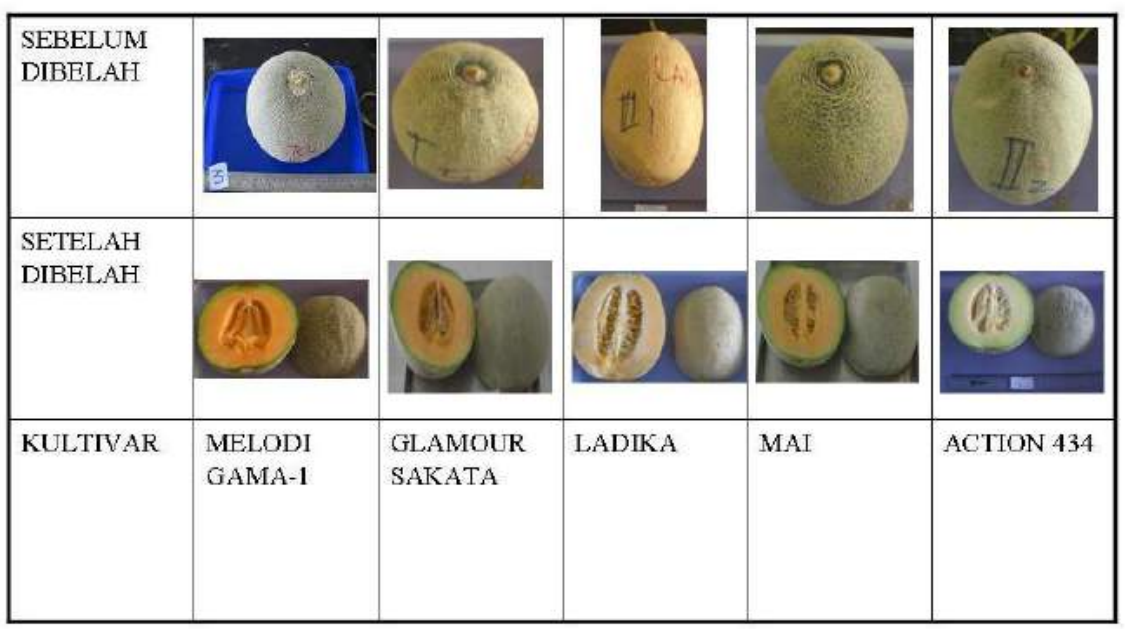

Gambar 1. Karakter fenotip melon kultivar Melodi Gama 1 dan 4 kultivar komersial lainnya (Maryanto, 2010)

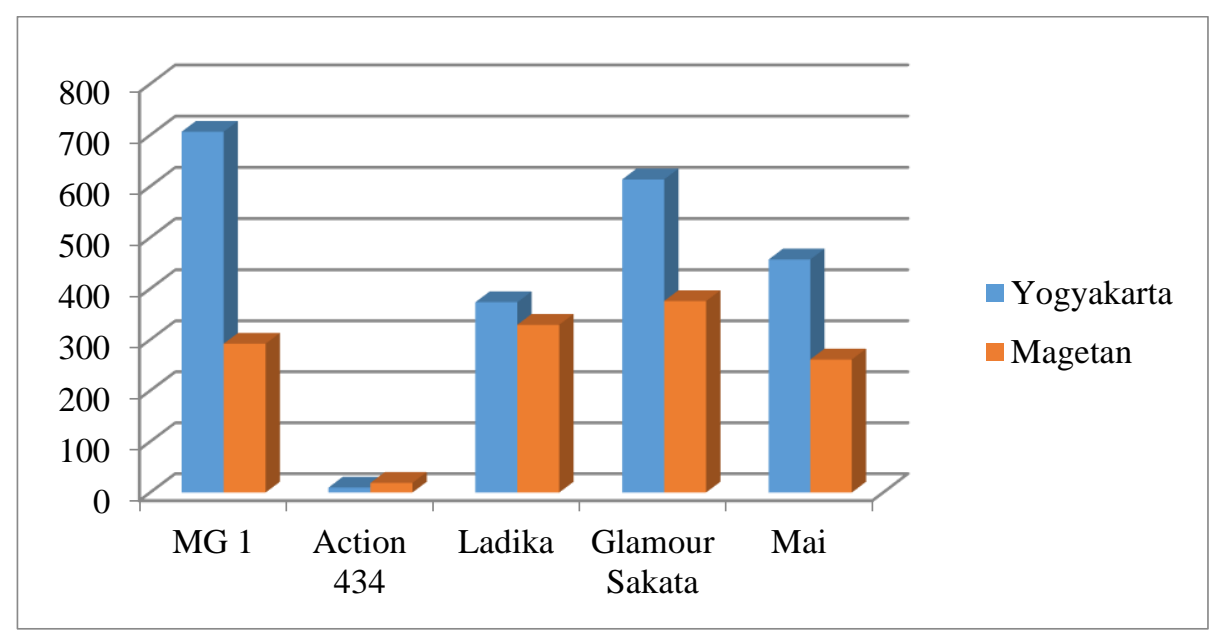

Gambar 2. Perbandingan total karoten kultivar Melodi Gama 1 dengan 4 kultivar komersial pada musim kemarau dari 2 lokasi penanaman yang berbeda

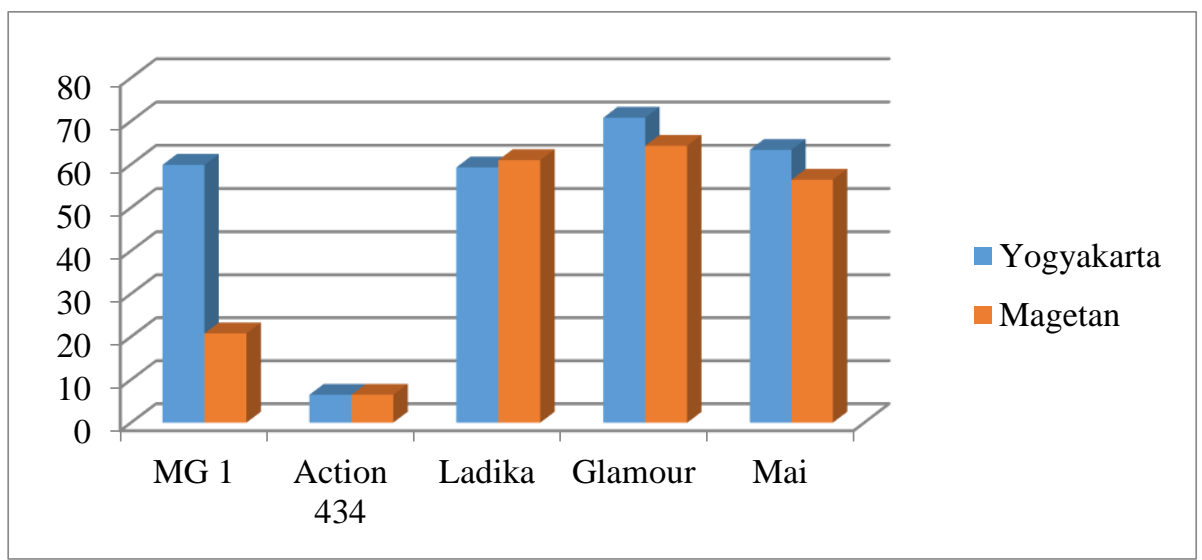

Gambar 3. Perbandingan total karoten kultivar Melodi Gama 1 dengan 4 kultivar komersial pada musim hujan dari 2 lokasi penanaman yang berbeda 


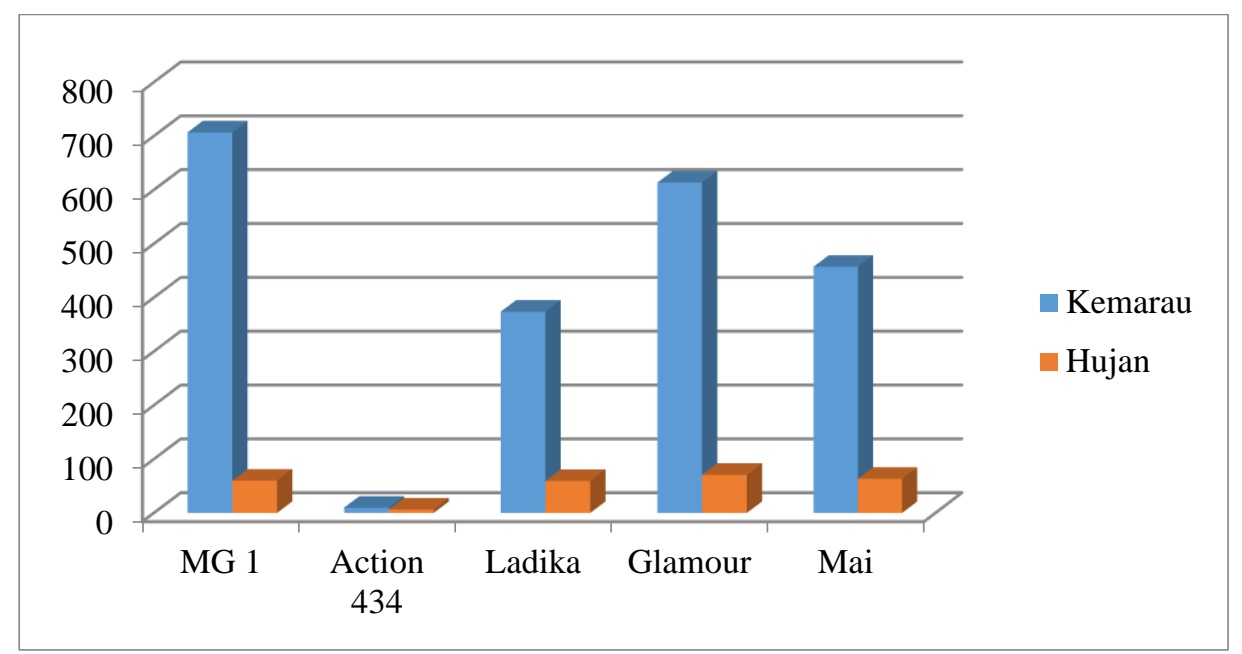

Gambar 4. Perbandingan total karoten kultivar Melodi Gama 1 dengan 4 kultivar komersial di lokasi penanaman Yogyakarta pada 2 musim yang berbeda

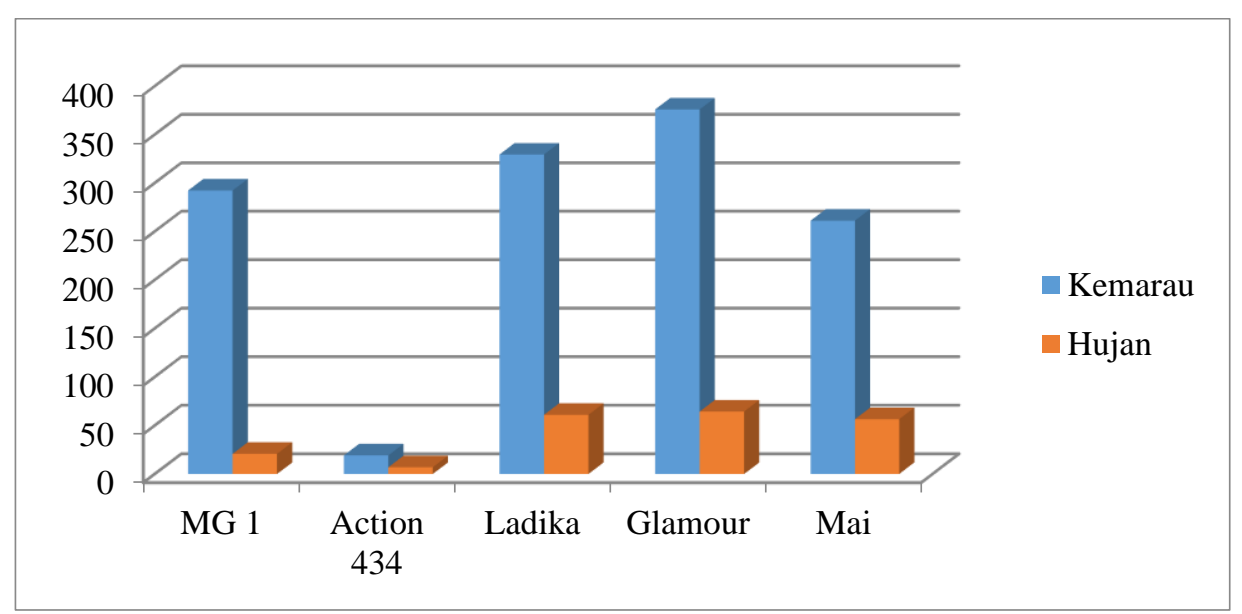

Gambar 5. Perbandingan total karoten kultivar Melodi Gama 1 dengan 4 kultivar komersial di lokasi penanaman Magetan pada 2 musim yang berbeda

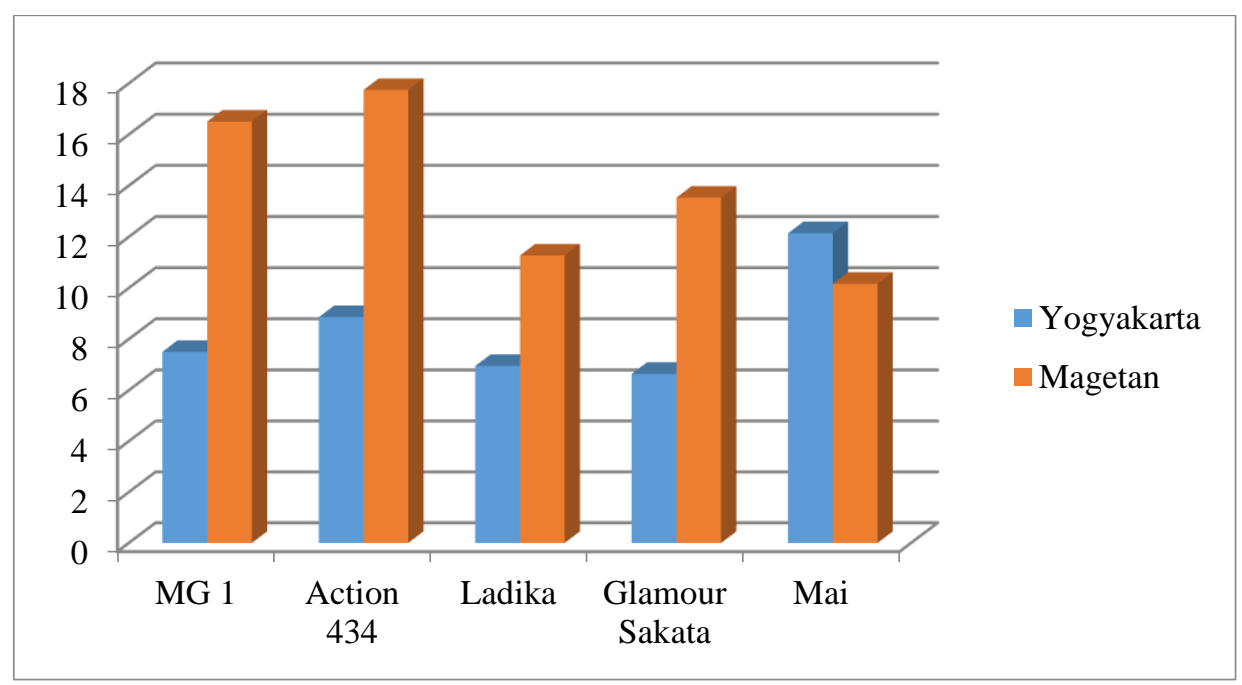

Gambar 6. Perbandingan kadar vitamin C kultivar Melodi Gama 1 dengan 4 kultivar komersial pada musim kemarau dari 2 lokasi penanaman yang berbeda 


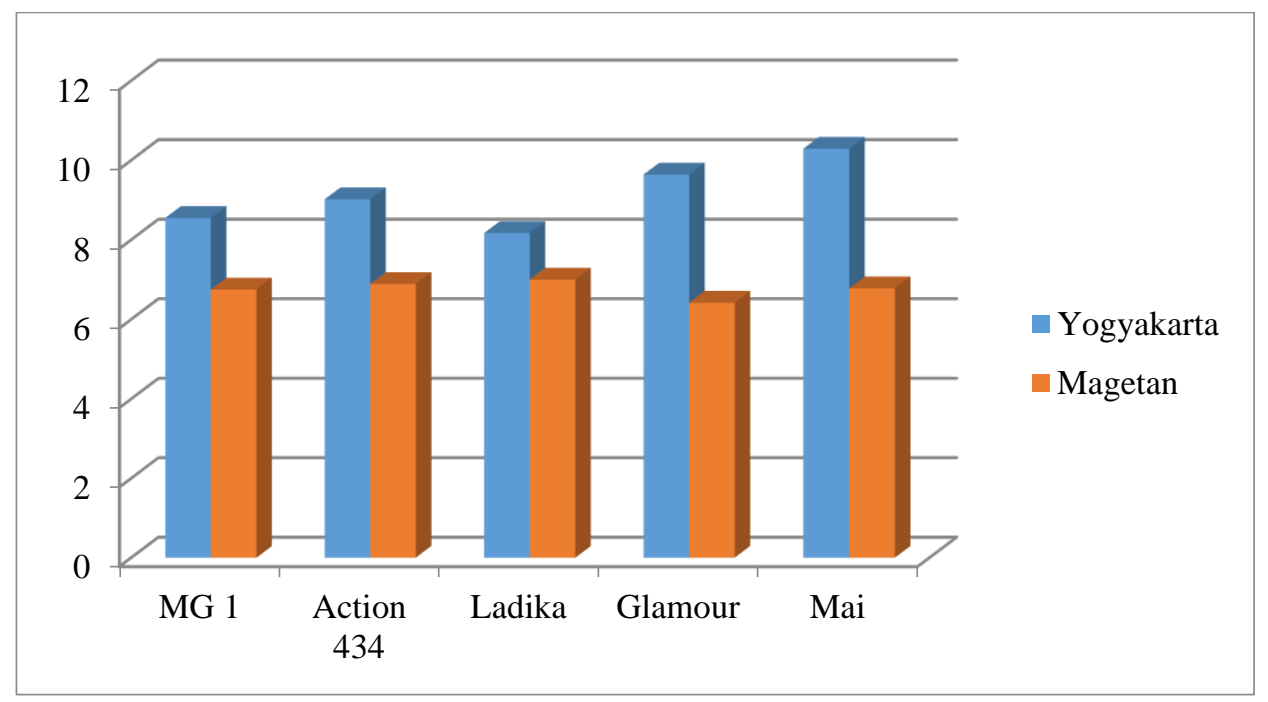

Gambar 7. Perbandingan kadar vitamin C kultivar Melodi Gama 1 dengan 4 kultivar komersial pada musim hujan dari 2 lokasi penanaman yang berbeda

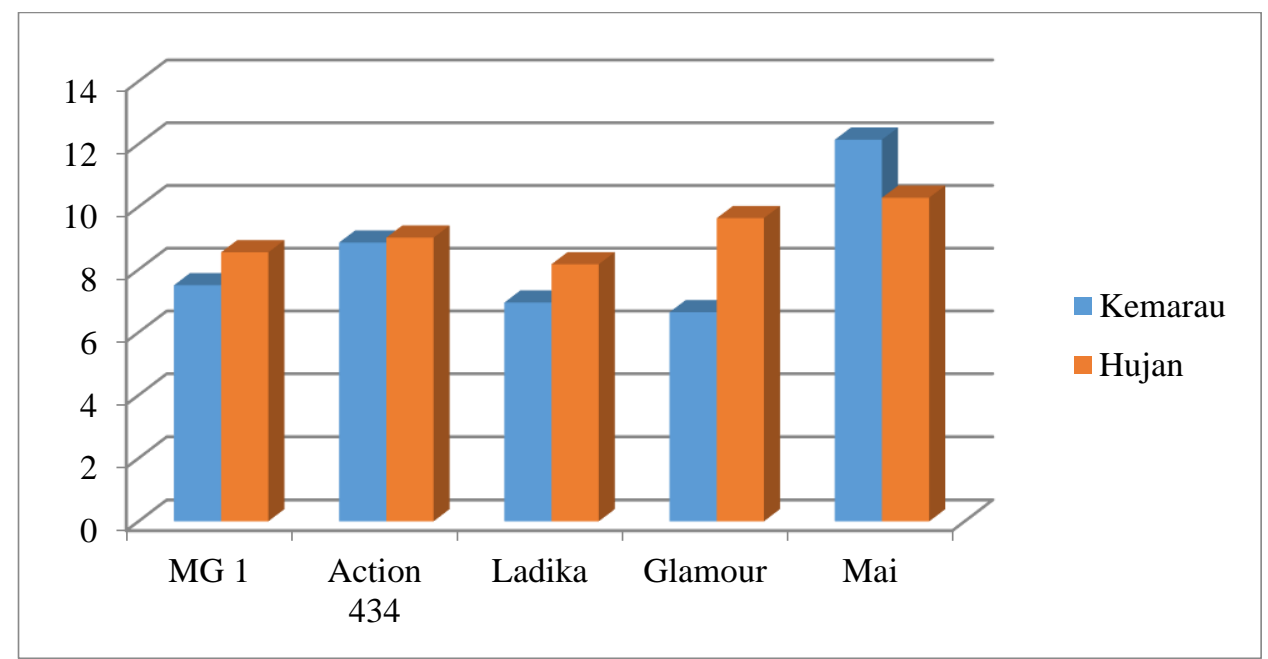

Gambar 8. Perbandingan kadar vitamin C kultivar Melodi Gama 1 dengan 4 kultivar komersial di lokasi penanaman Yogyakarta pada 2 musim yang berbeda

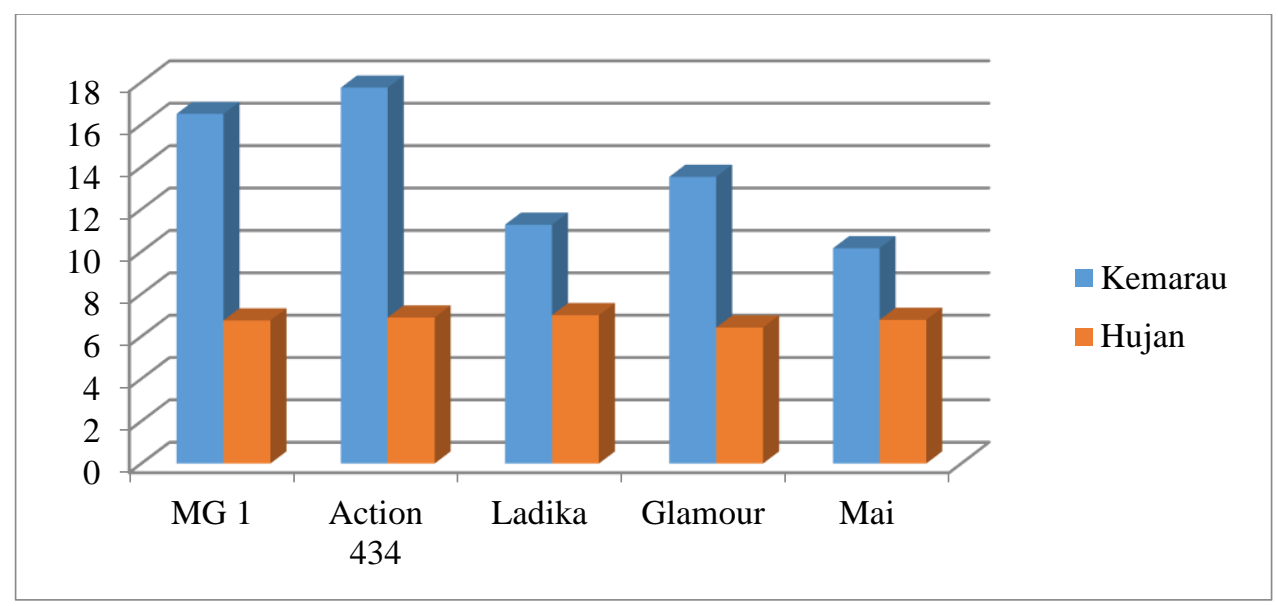

Gambar 9. Perbandingan kadar vitamin C kultivar Melodi Gama 1 dengan 4 kultivar komersial di lokasi penanaman Magetan pada 2 musim yang berbeda 


\section{PEMBAHASAN}

Kultivar Melodi Gama 1 merupakan hasil seleksi dari $\mathrm{TC}_{4}$ yaitu melon hasil uji silang (test cross) antara induk jantan $\mathrm{F}_{1} \mathrm{~B}$ dengan induk betina Andes (Alaydrus, 2008). Karakter fenotip kultivar Melodi Gama 1 antara lain bentuk buah bulat, kulit buah agak tebal dan keras, kulit buah berwarna hijau, nett jelas dan rapat, warna daging buah jingga (orange), tekstur daging buah lembut, aroma harum, dan rasa manis (Maryanto and Daryono, 2011).

Dalam penelitian ini, 4 kultivar komersial yang digunakan antara lain Action 434, Glamour Sakata, Mai, dan Ladika. Kultivar Action 434, Glamour Sakata, dan Mai memiliki karakter bentuk buah bulat seperti kultivar Melodi Gama 1, sedangkan Ladika memiliki bentuk buah lonjong. Kultivar Melodi Gama 1 memiliki warna daging buah jingga (orange) seperti karakter pada kultivar Glamour Sakata, Mai, dan Ladika, sedangkan Action 434 memiliki warna daging buah hijau (Gambar 1). Daging buah yang berwarna jingga (orange) mengandung banyak beta karoten dan provitamin A. Warna jingga pada daging buah melon dikontrol oleh single dominant gene (Fukino et al., 2004). Daging buah warna jingga (orange) bersifat dominan sedangkan daging buah hijau bersifat resesif.

Hasil dari uji total karoten terhadap kultivar Melodi Gama 1 dengan 4 kultivar komersial lainnya pada musim kemarau dan musim hujan pada lokasi penanaman Yogyakarta dan Magetan dapat dilihat pada Gambar 2 dan 3. Berdasarkan Gambar 2 menunjukkan bahwa pada musim kemarau kultivar Melodi Gama 1 yang ditanam di Yogyakarta memiliki kandungan karoten tertinggi yaitu 706,61 $\mu \mathrm{g} / 100 \mathrm{gr}$ dibandingkan kultivar Action 434, Glamour Sakata, Mai, dan Ladika. Pada hasil tersebut terlihat bahwa kultivar Action 434 memiliki kandungan karoten terendah dibandingkan kultivar lainnya. Hal ini karena kultivar Action 434 memiliki karakter fenotip daging buah berwarna hijau, sedangkan 4 kultivar lain yaitu Melodi Gama 1, Glamour Sakata, Ladika, Mai memiliki warna daging buah jingga (orange). Sedangkan pada lokasi penanaman di Magetan menunjukkan bahwa nilai karoten tertinggi pada kultivar Glamour Sakata yaitu 375,86 $\mu \mathrm{g} / 100 \mathrm{gr}$, sedangkan kultivar Melodi Gama 1 hanya memiliki total karoten yaitu 292,16 $\mu \mathrm{g} / 100 \mathrm{gr}$.

Berdasarkan Gambar 3 menunjukkan bahwa pada musim hujan kultivar Melodi Gama 1 yang ditanam di Yogyakarta memiliki total karoten yang termasuk tinggi yaitu 59,88 $\mu \mathrm{g} / 100 \mathrm{gr}$, namun untuk total karoten tertinggi yaitu kultivar Glamour Sakata yaitu $70,77 \mu \mathrm{g} / 100 \mathrm{gr}$. Untuk nilai yang terendah yaitu kultivar Action 434 sebesar $6,48 \mu \mathrm{g} / 100 \mathrm{gr}$. Sedangkan untuk lokasi penanaman di Magetan total karoten tertinggi pada kultivar Glamour Sakata 64,29 $\mu \mathrm{g} / 100 \mathrm{gr}$ yaitu sedangkan kultivar Melodi Gama 1 hanya sebesar $20,76 \mu \mathrm{g} / 100 \mathrm{gr}$. Untuk nilai yang terendah di lokasi Magetan yaitu kultivar Action 434 sebesar 6,90 $\mu \mathrm{g} / 100 \mathrm{gr}$.

Hasil yang ditunjukkan pada Gambar 2 dan 3 mengindikasikan bahwa lokasi penanaman tidak mempengaruhi kandungan total karoten pada buah melon. Total karoten lebih banyak dipengaruhi warna daging buahnya. Daging buah yang berwarna jingga (orange) memiliki kandungan yang lebih tinggi dibandingkan buah yang memiliki warna daging buah hijau. Vitamin A banyak terdapat dalam sayuran dan buah berwarna kuning-oranye karena karotenoid merupakan pigmen yang larut dalam lemak berwarna kuning sampai merah dan terdapat pada tumbuhan dan berbagai jenis jaringan. Pigmen karotenoid ini banyak ditemukan pada absorbansi dengan $\lambda=450 \mathrm{~nm}$ (Gardjito dan Wardana, 2003).

Hasil pengaruh musim terhadap total karoten pada kultivar Melodi Gama 1 dan 4 kultivar komersial lainnya dapat dilihat pada Gambar 4 dan 5. Berdasarkan Gambar 4 menunjukkan bahwa pada lokasi penanaman Yogyakarta musim sangat mempengaruhi total karoten buah melon. Pada musim kemarau total karoten sangat tinggi dibandingkan musim hujan. Pada musim kemarau, kultivar Melodi Gama 1 memiliki total karoten tertinggi sebesar 706,61 $\mu \mathrm{g} / 100 \mathrm{gr}$ dan terendah pada kultivar Action 
434 sebesar 9,68 $\mu \mathrm{g} / 100 \mathrm{gr}$. Pada musim hujan, total karoten tertinggi yaitu kultivar Glamour Sakata sebesar 70,77 $\mu \mathrm{g} / 100 \mathrm{gr}$ dan terendah kultivar Action 434 sebesar 6,48 $\mu \mathrm{g} / 100 \mathrm{gr}$.

Berdasarkan Gambar 5 menunjukkan bahwa pada lokasi penanaman Magetan musim juga mempengaruhi total karoten buah. Pada musim hujan total karoten tidak terlalu tinggi dibandingkan dengan musim kemarau. Pada musim kemarau, kultivar Glamour Sakata memiliki kandungan total karoten tertinggi sebesar 375,86 $\mu \mathrm{g} / 100 \mathrm{gr}$ dan terendah pada kultivar Action 434 sebesar 19,12 $\mu \mathrm{g} / 100 \mathrm{gr}$. Pada musim hujan, total karoten tertinggi yaitu kultivar Glamour Sakata sebesar 64,29 $\mu \mathrm{g} / 100 \mathrm{gr}$ dan terendah pada kultivar Action 434 sebesar 6,90 $\mu \mathrm{g} / 100 \mathrm{gr}$.

Hasil mengenai pengaruh lokasi penanaman terhadap kandungan vitamin $\mathrm{C}$ pada buah melon dapat dilihat pada Gambar 6 dan 7. Berdasarkan Gambar 6 dan 7 menunjukkan bahwa lokasi penanaman tidak berpengaruh terhadap kadar vitamin $\mathrm{C}$ pada buah melon. Pada musim kemarau, kadar vitamin $\mathrm{C}$ pada lokasi penanaman Magetan lebih tinggi dibandingkan dengan Yogyakarta. Pada lokasi Yogyakarta, kadar vitamin C tertinggi pada kultivar Mai sebesar 12,14 $\mathrm{mg} / 100 \mathrm{~g}$ dan terendah kultivar Ladika sebesar $6,95 \mathrm{mg} / 100 \mathrm{~g}$. Sedangkan di lokasi penanaman Magetan, kadar vitamin C tertinggi pada kultivar Action 434 sebesar $17,74 \mathrm{mg} / 100 \mathrm{~g}$ dan terendah kultivar Mai $10,16 \mathrm{mg} / 100 \mathrm{~g}$. Untuk musim hujan kadar vitamin $\mathrm{C}$ di lokasi Yogyakarta lebih tinggi dibandingkan Magetan. Kadar vitamin C tertinggi di Yogyakarta terdapat pada kultivar Mai sebesar 10,29 dan terendah kultivar Ladika sebesar 8,17. Sedangkan di lokasi penanaman Magetan kadar vitamin C memiliki nilai yang relatif sama.

Hasil mengenai pengaruh musim terhadap kadar vitamin $\mathrm{C}$ dapat dilihat pada Gambar 8 dan 9

Berdasarkan Gambar 8 dan 9 terlihat bahwa musim tidak memiliki pengaruh yang signifikan terhadap kandungan vitamin $\mathrm{C}$. Pada musim kemarau dan hujan di lokasi
Yogyakarta, kadar vitamin $\mathrm{C}$ tertinggi terdapat pada kultivar Mai sebesar 12,14 $\mathrm{mg} / 100 \mathrm{~g}$ dan 10,29 mg/100 g. Sedangkan pada lokasi Magetan pada musim kemarau terdapat pada kultivar Action 434 17,74 $\mathrm{mg} / 100 \mathrm{~g}$ sebesar dan terendah kultivar Mai sebesar 10,16 mg/100 g, sedangkan pada musim hujan kadar vitamin $\mathrm{C}$ relatif sama. Namun secara keseluruhan kadar vitamin $\mathrm{C}$ pada musim hujan mengalami penurunan dibandingkan saat musim kemarau. Hal ini kemungkinan disebabkan oleh sifat dari vitamin $\mathrm{C}$ yang larut dalam air sehingga menyebabkan kadar air yang meninngkat pada musim hujan berakibat penurunan kadar vitamin $\mathrm{C}$.

\section{KESIMPULAN}

1. Lokasi penanaman tidak berpengaruh terhadap total karoten dan kadar vitamin C pada buah melon

2. Musim berpengaruh terhadap total karoten dan kadar vitamin $\mathrm{C}$ yaitu ditunjukkan bahwa pada musim hujan nilainya akan menurun dibandingkan saat musim kemarau.

3. Kultivar Melodi Gama 1 sebagai kultivar baru hasil perakitan memiliki total karoten dan kadar vitamin $\mathrm{C}$ yang tinggi sehingga dapat digunakan sebagai buah konsumsi dengan nilai gizi yang baik.

4. Total karoten yang tinggi pada daging buah melon ditandai dengan warna jingga (orange) yang dikontrol oleh single dominant gene.

\section{UCAPAN TERIMA KASIH}

Penelitian ini didanai oleh Hibah Kompetensi tahun 2009-2011 No: 238/SP2H/PP/DP2M/V/2009-2011. Penulis juga mengucapkan terima kasih kepada Laboratorium Genetika Fakultas Biologi UGM, Kebun Pendidikan Penelitian dan Pengembangan Pertanian (KP4) UGM, serta Fakultas Teknologi Pertanian UGM atas bantuan fasilitas penelitian.

\section{DAFTAR PUSTAKA}

Alaydrus Y. 2008. Pemuliaan dan Pewarisan Sifat Ketahanan terhadap Kyuri green 
mottle mosaic virus (KGMMV) pada Melon (Cucumis melo L.) [Tesis]. Yogyakarta: Program Pascasarjana Fakultas Biologi Universitas Gadjah Mada, hal 67-79.

Almatsier S. 2004. Prinsip Dasar Ilmu Gizi. Jakarta: Gramedia Pustaka Utama.

Daryono BS dan Aristya GR. 2009. Penelitian Pengembangan Melon (Cucumis melo L.) Kultivar Melodi Gama-1. Laporan Penelitian. Yogyakarta: Fakultas Biologi Universitas Gadjah Mada.

Daryono BS, Maryanto SD, Huda IN. 2011. Kebangkitan Pertanian Indonesia. Yogyakarta: Kebun Pendidikan Penelitian Pengembangan Pertanian (KP4) Universitas Gadjah Mada.

Fukino N, Kunisiha M, Matsumoto S. 2004. Characterization of Recombinant Inbred Lines Derived from Crosses in Melon (Cucumis melo L.) PMAR No.5 Haruke No3. Journal Breeding Science 54: 141145.

Gardjito M dan Wardana AS. 2003. Hortikultura Teknik Analisis Pasca Panen. Yogyakarta: Transmedia Mitra Printika. hal: 29-31.
Maryanto SD. 2010. Perbandingan Karakter fenotip Buah Melon (Cucumis melo L.) Kultivar Melodi Gama 1, Gama Melon Basket, dan Kultivar melon Komersial Pada Uji Multilokasi dan Multimusim. [Skripsi]. Yogyakarta: Fakultas Biologi Universitas Gadjah Mada.

Maryanto SD and Daryono BS. 2011. The Comparison of Melon (Cucumis melo L.) Phenotypic Characters among Melodi Gama 1, Gama Melon Basket, and Commersial Cultivars Using Multilocation and Multiseason Test In Indonesia. Proceeding in Pasific Science Congress XXII; 14-17 Juni 2011, Kuala Lumpur. p:164

Poedjiadi A dan Supriyanti FMT. 2006. Dasar-Dasar Biokimia. Jakarta: Universitas Indonesia. hal: 397, 409.

Prajnanta F. 2004. Pemeliharaan secara Intensif dan Kiat Sukses Beragrobisnis Melon. Jakarta: PT Penebar Swadaya. hal 1-5, 8-12.

Winarno FG. 2008. Kimia Pangan dan Gizi. Bogor: M-Brioo Press.

World Health Organization. 2010. The World Health Report. Geneva: WHO. www.who.int. 